\title{
Doing Anthropology in Russian Military Uniform ${ }^{1}$
}

\author{
Marina MogILner
}

The interplay between two of the most significant categories in post-Hegelian European modernity-total war and race-has not been subject to analysis within the narrative of Russian history. "Race" was seen as the natural, historically conditioned human collective, a synthesis between a discrete human subspecies and the unique artefact of its "spirit." "Total war" was regarded in certain circles as an ideal mechanism for the selection of peoples of superior vitality, able collectively to sustain long-term military, economic, cultural and political competition. Total war would pit nation against nation, each combatant's resolve cemented by "national" values and interests, "natural" virtues, and "organic" racial traits. The reasons for this abstinence have been several: Russian involvement in World War I has been overshadowed by the nearly concurrent traumata of the 1917 revolutions and the civil war that followed. The war's role as both the climax of Russian prerevolutionary development and the cradle of many Soviet discourses and practices is gaining appreciation, only now, in the history writing of the past decade. ${ }^{2}$

1 Research for this article was supported by the Gerda Henkel Stiftung (AZ 09/ $\mathrm{SR} / 02$ ) and the Volkswagen Stiftung (grant in support of the collaborative project "Languages of self-description and representation of the Russian Empire," 2006). I am grateful to all the participants of the conference "Doing Anthropology in Wartime and War Zones" for their stimulating comments and questions.

2 Dietrich Beyrau, Militär und Gesellschaft im vorrevolutionären Russland (Cologne: Böhlau, 1984); N. N. Smirnov et al., eds., Rossiia i Pervaia mirovaia voina, Materialy mezhdunarodnogo nauchnogo kollokviuma (St. Petersburg: Dmitrii Bulanin, 1999); Peter Gatrell, A Whole Empire Walking: Refugees in Russia during World War I (Bloomington, IN: Indiana University Press, 1999); Josh Sanborn, "The Mobilization of 1914 and the Question of the Russian Nation: A Reexamination," Slavic Review 59, no. 2 (2000): 267-289; Peter Holquist, 
As for race, scholars' indifference toward its role in Russian culture and politics can be traced to a dominant Sonderweg perception of Russian modernity as underdeveloped and derivative, incapable of generating modern liberal, national, colonial, or gender discourses, institutions, or practices. ${ }^{3}$ Tacit recog-

Making War, Forging Revolution: Russia's Continuum of Crisis, 1914-1921 (Cambridge, MA: Harvard University Press, 2002); Joshua Sanborn, Drafting the Russian Nation: Military Conscription, Total War, and Mass Politics, 1905-1925 (Dekalb, IL: Northern Illinois Press, 2003); Eric Lohr, Nationalizing the Russian Empire: The Campaign against Enemy Aliens during World War I (Cambridge, MA: Harvard University Press, 2003); Melissa K. Stockdale, "United in Gratitude: Honoring Soldiers and Defining the Nation in Russia's Great War," Kritika: Explorations in Russian and Eurasian History 7, no. 3 (2006): 459-486.

3 See the discussion of the implications of the Sonderweg paradigm for Russian history in Ab Imperio 3, no. 1 (2002): 15-101 (contributions by Carl E. Schorske, Hans van der Loo, Gunilla-Friederike Budde, Jürgen Kocka, and Manfred Hildermeier). Race was, and remains, an important issue for historians studying Russian politics toward Jews. This is the result of their "socialization" in general Jewish historiography rather than in Russian history. See Hans Rogger, Jewish Policies and Right-Wing Politics in Imperial Russia (Berkeley, CA: University of California Press, 1986); Eli Weinerman, "Racism, Racial Prejudice and Jews in Late Imperial Russia," Ethnic and Racial Studies 17, no. 3 (1994): 442-495; the most recent example: Eugene Avrutin, "The Power of Documentation: Vital Statistics and Jewish Accommodation in Tsarist Russia," Ab Imperio 4, no. 4 (2003): 271-300; idem, "The Politics of Jewish Legibility: Documentation Practices and Reform during the Reign of Nicholas I," Jewish Social Studies 11, no. 2 (2005): 136-169; idem, "Racial Categories and the Politics of (Jewish) Difference in Late Imperial Russia," Kritika: Explorations in Russian and Eurasian History 8, no. 1 (2007): 13-40; Marina Mogilner, "Evreiskaia antropologia v Rossii v kontekste evropeiskikh rasovykh issledovanii," in Istoriia i Kul'tura Rossiiskogo i Vostochnoevropeiskogo Evreistva: Novye istochniki, novye podkhody, eds. Oleg Budnitskii et al. (Moscow: Dom evreiskoi knigi, 2004), 116-137. Students of Soviet history also had additional incentives to consider race as a part (or not a part) of Russian modernity. See Eric Weitz, "Racial Politics without the Concept of Race: Reevaluating Soviet Ethnic and National Purges," Slavic Review 61, no. 1 (2002): 1-29; Paul Weindling, "German-Soviet Medical Co-operation and the Institute for Racial Research," German History 10, no. 2 (1992): 177-206. As an example of a new emerging interest in race in the post-Soviet countries, see Vladimir B. Avdeev and A. N. Savel'ev, eds., Rasovyi smysl Russkoi idei: Sbornik Statei (Moscow: Belye Al'vy, 2000); Vladimir B. Avdeev, ed., Russkaia rasovaia teoriia do 1917 goda: Sbornik original'nykh rabot russkikh klassikov (Moscow: Feri-V, 2002); Vladimir Menzhulin, Drugoi Sikorskii: Neudobnye stranitsy istorii psikhiatrii (Kyiv: Sfera, 2004). On Russian modernity and its resistance to biological determinism, see Laura Engelstein, Keys to Happiness: Sex and the Search for Modernity in Fin-de-Siècle Russia (Ithaca, NY: Cornell University Press, 1992); 
nition of the atypical character of Russia's contiguous Empire contributed to the production of colonial and anticolonial discourses that avoided recourse to standard European imperial categories such as race. ${ }^{4}$ As a result, the story of Russian "race studies" has to be written virtually from scratch. But even initial steps reveal a substantial and highly differentiated tradition of physical anthropology in the Russian Empire. ${ }^{5}$ Despite the differing modes of anthropology's institutionalization and the fluidity of major anthropological paradigms, the fact remains that anthropology established itself as a legitimate academic field in Russia in the 1870s.

The first Russian chair in anthropology was established at Moscow University in $1879^{6}$ - the same year the first German professorship was bestowed on Johannes Ranke in Munich. ${ }^{7}$ Remarkably, this first and major Russian professorship subsisted on private donations, as did the Anthropological Division of the Moscow-based Society of the Lovers of the Natural Sciences, Anthropology and Ethnography (1863) that had raised the money to fund it. ${ }^{8}$ The Anthropological Division was the real center of Russian anthropology, connected with other academic societies and individuals engaged in anthropological research across the Empire. Again, this was not a uniquely Russian form of institutionalization; ${ }^{9}$ what made Russia unusual was the clear linking of partic-

James Allen Rogers, "Charles Darwin and Russian Scientists," Russian Review 19, no. 4 (1960): 371-383.

4 The classical work in this regard remains the dissertation by Nathaniel Knight, "Constructing the Science of Nationality: Ethnography in Mid-Nineteenth Century Russia" (PhD thesis, Columbia University, 1995); see also his "Ethnicity, Nationality, and the Masses: Narodnost' and Modernity in Imperial Russia," in Russian Modernity: Politics, Knowledge, Practices, eds. David L. Hoffmann and Yanni Katsonis (New York: St. Martin's Press, 2000), 41-66.

5 See Marina Mogilner, Homo Imperii: Istoriia fizicheskoi antropologii v Rossiiskoi imperii (konets XIX-nachalo XX vv.) [Homo imperii: A history of physical anthropology in the Russian Empire, late 19th to early 20th centuries] (Moscow: Novoe Literaturnoe Obozrenie, 2008).

6 The detailed history of the chair is reconstructed on the basis of archival materials from the Moscow Central Historical Archive (TsIAM. F. 418. Op. 48. D. 422; F. 428. Op. 46. D. 339.) in Mogilner, Homo Imperii. See also N. G. Zalkind, Moskovskaia shkola antropologii v razvitii otechestvennoi nauki o cheloveke (Moscow: Nauka, 1974).

7 Paul Weindling, Health, Race and German Politics between National Unification and Nazism, 1870-1945 (Cambridge, UK: Cambridge University Press, 1989), 54.

8 The Society received the donation from the industrialist K. F. von Mekk. See TsIAM. F. 428. Op. 46. D. 339. L. 2-10; L. 67-67 rev.

9 On the German pattern of anthropological institutionalization, see Andrew Zimmerman, Anthropology and Antihumanism in Imperial Germany (Chicago, IL: University of Chicago Press, 2001). 
ular varieties of political and anthropological discourse to particular anthropological societies - all equally alienated from, and ignored by, officialdom.

\section{Three Competing Schools and a Pluralistic Army}

The Moscow Anthropological Division became the stronghold of the liberal anthropology of imperial diversity, heavily influenced by the German tradition of Rudolf Virchow. The Moscow scholars embraced a very broadly defined liberal, universalistic, and optimistic political outlook based on ideas of human unity, monogenism, and evolutionism. ${ }^{10}$ The school studied not "races" but "physical types." Its project of a comprehensive anthropological survey of the population of the Russian Empire aimed at establishing "degrees of kinship" and types of interaction, rather than hierarchies. It adhered to the existing official prenational nomenclature of peoples, abstaining from the construction of larger national entities; refused to equate race and nation or to support any racial hierarchies, whether inside or outside Europe or Russia proper; and studied both the Russian and non-Russian peoples of the Empire, viewing the imperial borders as the natural limits of a not yet "anthropologically rationalized" Russian Empire, a coming anthropological utopia. ${ }^{11}$ Many members of this immensely influential school were liberal opponents of the regime, while its leader, Professor Dmitrii Nikolaevitch Anuchin, ${ }^{12}$ could be called the

10 For a detailed treatment of Virchow's "liberal anthropology," see Andrew D. Evans, "A Liberal Paradigm? Race and Ideology in Late-Nineteenth-Century German Physical Anthropology," Ab Imperio 8, no. 1 (2007): 113-138.

11 An influential Moscow anthropologist, Alexander A. Ivanovkii, proposed a kind of synthesis of these approaches in his racial "classification" of the Russian Empire: Idem, "Ob antropologicheskom sostave naseleniia Rossii," Izvestia Imperatorskogo Obshchestva Liubitelei estestvoznaniia, antropologii i etnografii: Trudy Antropologicheskogo otdela XXII (1904): 1-287, 4 maps.

12 V. V. Bogdanov, Dmitrii Nikolaevitch Anuchin: Sbornik v chest' semidesiatiletiia Dmitriia Nikolaevitcha Anuchina (Moscow: IOLEAE, 1913), VII-XL; about Anuchin's career as the Moscow university anthropology professor, see TsIAM. F. 418. Op. 86. D. 547. LI. 9-20; V. V. Bunak, "Deiatel'nost' D. N. Anuchina v oblasti antropologii," Russkii Antropologicheskii Zhurnal 13, nos. 3-4 (1924): 1-18; L. S. Berg, "Dmitrii Nikolaevitch Anuchin (1843-1923)," in Ocherki po istorii russkikh geograficheskikh otrkytii, ed. L. S. Berg (Moscow-Leningrad: SSSR's Academy of Science, 1946), 282-318. The list of Anuchin's scholarly works published before 1913, see Bogdanov, Dmitrii Nikolaevitch Anuchin, xxiv-xxvii; works published between 1913 and 1923 were catalogued by N. A. Sinel'nikov and published by B. B. Bunak in Russkii Antropologicheskii Zhurnal 13, nos. 3-4 (1924): 17-18. 
Russian Virchow both for his scientific views and for his ability to keep the anthropological community within the bounds of the liberal paradigm. ${ }^{13}$

The Russian Anthropological Society at St. Petersburg University (1884/88) chose colonial anthropology as its model and promoted an expert ethos. Its traditional orientation was toward French physical anthropology. The school expressed loyalty to the regime and a desire to become the official science of the modern Empire. Although its membership and ideology evolved with time, its elitist, expert-oriented discourse and contempt for public opinion, with its focus on the anthropology of imperial minorities, persisted until the eve of the Great War. ${ }^{14}$ The state, for its part, proved uninterested in the expertise offered by the St. Petersburg anthropologists and unwilling to support their initiatives to modernize imperial rule. The Imperial Ministry of Education modestly funded the Moscow Anthropological Division's Russian Anthropological Journal as a matter of course, because it was a well-established journal. As it was the major mouthpiece of liberal anthropologists, the Ministry therefore unintentionally helped to spread their political influence across the Empire, ${ }^{15}$ while the St. Petersburg Russian Anthropological Society was denied even

13 See Anuchin's interpretation of Virchow's anthropology in Dmitrii Nikolaevitch Anuchin, "R. Virkhov kak antropolog," Russkii Antropologicheskii Zhurnal VII-VIII, nos. 3-4 (1901): X-XXXII. For more on Anuchin and Virchow in the Russian context, see Marina Mogilner, "Russian Physical Anthropology in Search for 'Imperial Race': Liberalism and Modern Scientific Imagination in the Imperial Situation," Ab Imperio 8, no. 1 (2007): 191-223.

14 On the Russian Anthropological Society, see the Central State Historical Archive of St. Petersburg (TsGIASPb), F. 14. Op. 1. D. 8591; Op. 1. Vol. 4. D. 9045; "Ustav Russkogo Antropologicheskogo Obshchestva [RAO] pri S.-Peterburgskom Universitete," in Protokoly zasedanii RAO pri IPU za 1895/6 god, ed. V. Ol'derogge (St. Petersburg: RAO, 1898), 3-6; L. P. Nikol'skii, "Pamiati Professora Eduarda Jul'evicha Petri," Trudy Antropologicheskogo Obshchestva pri Voenno-Meditsinskoi academii (1899-1900 academic year) VI (1900): 3-8; "Russkoe Antropologicheskoe Obshchestvo pri Peterburgskom universitete," Russkii Antropologicheskii Zhurnal VII-VIII, nos. 1-2 (1904): 233; I. L. Tikhonov, Arkheologia $v$ Sankt-Peterburgskom universitete: Istoriograficheskie ocherki (St. Petersburg: Izdatel'stvo SPb. universiteta, 2003), appendix. For an extensive treatment, see Mogilner, Homo Imperii.

15 The first issue of Russkii Antropologicheskii Zhurnal was published in 1900. Its predecessor was "The Diary of the Anthropological Division" [Dnevnik Antropologicheskogo otdela] published in 1890-1893 in three volumes (20 issues). Russkii Antropologicheskii Zhurnal remained a regular publication until 1906 when a fire in the printing shop and financial problems hampered its regular production. The journal was not published between 1908 and 1911 or between 1914 and 1915. It reemerged in 1916, was interrupted by the revolutions of 1917 and did not appear again regularly until 1924. 
small subsidies for its publications since they were regarded by the Ministry as redundant. ${ }^{16}$

Kiev University became the major locus of Russian nationalist anthropology. Ivan Alekseevich Sikorskii, a professor of psychiatry, was its leading proponent of ethnic Russian racial nationalism. ${ }^{17}$

Other local versions of Russian imperial anthropology can be found in conjunction with one of these three major centers. ${ }^{18}$ Yet, their continuing dialogue and overt or implicit references to major paradigms permit us to speak of Russian imperial anthropology as a cohesive phenomenon. It was characterized not only by a shared focus on the peoples of the Russian Empire, but also by its self-organization. The anthropological movement was largely left to its own devices by an indifferent and generally incurious state apparatus, with the result that anthropology and the state were alienated from one another. The state's hands-off attitude failed to encourage the establishment of a single dominant paradigm of race science conceived as an instrument of imperial politics.

It is against this background that one should approach Russian military anthropology. Among the many currents within the heterogeneous space of Russian imperial anthropology, it was the only one acknowledged and in active use by the state itself. As an applied science, it collapsed with the disintegration of the army after 1917, along with the War Ministry that had determined how,

16 Russian State Historical Archive, F. 733. Op. 144. D. 3 "O naznachenii posobii uchenym Obshchestvam, uchrezhdeniam i litsam," 1904; Russian State Historical Archive, F. 733. Op. 145. D. 3 "O naznachenii posobii uchenym Obshchestvam, uchrezhdeniam i litsam". LI. 1-92, etc.

17 On the history of Sikorskii's anthropological initiatives in Kiev, see Kiev City Archive (GAK). F. 16. Op. 465. D. 255. LI. 25-28; Central State Historical Archive of Ukraine (TsGIAU). F. 707. Op. 262. D. 8. 8 II.; Marina Mogilner, “Entsiklopedia russkogo natsionalisticheskogo proekta," Ab Imperio 4, no. 3 (2003): 225-240; Menzhulin, Drugoi Sikorskii. All of Sikorskii's major works have been recently reprinted by today's supporters of Russian racial nationalism in Avdeev, Russkaia rasovaia teoriia do 1917 goda.

18 About different centers of Russian physical anthropology, see Mogilner, Homo Imperii. For more or less general contemporary accounts, see Fedor Volkov, "Antropologia i ee universitetskoe prepodavanie (K peresmotru universitetskogo ustava)" in Ezhegodnik RAO pri Imperatorskom Petrogradskom universitete, ed. S. I. Rudenko (Petrograd: RAO, 1915), 99-107; Idem, "K voprosu o prepodavanii antropologii v Kazanskom universitete," Zhurnal Kazanskogo Mediko-Antropologicheskogo Obshchestva 1 (1921): 272; E. G. Landau, Kratkoe rukovodstvo k izucheniu antropologii (Jur'ev: University Press, 1912); R. L. Veinberg, "Glavneishie priiemy sovremennoi antropologicheskoi tekhniki (Iz antropologicheskoi laboratorii Jur'evskogo anatomicheskogo instituta)," Russkii Antropologicheskii Zhurnal XVII-XVIII, nos. 1-2 (1904): 79-120 and all issues of Russkii Antropologicheskii Zhurnal. 
where, and to whom its science would be "applied." However, many campaigns fought by European anthropologists during and after the war had been waged by Russian military anthropologists before the war began. They had confronted the supposed "impractical" nature of liberal anthropology; worked both for and against "European" Others within the Empire; fought the temptation to exploit ready-made European blueprints in structurally colonial situations marked by the presence of Others within the imperial borders; and advocated for a hygienic alliance with the state.

As elsewhere, the Great War compromised a liberal tradition. Russian anthropology's central figures abandoned the project of a self-mobilizing anthropological community to join state-sanctioned committees for the study of population as a "productive force," 19 and many ordinary practitioners turned toward more radical nationalist or socialist ideologies. But in contrast to some European nations, the war did not provide incentives for Russian military anthropologists to expand their scope. To get a good look at the Other, scientists hardly needed prisoner-of-war (POW) camps; they had been traveling the Empire for years. Accordingly, they did not share the excitement of German ${ }^{20}$ and Austrian colleagues who gained access to POWs. Likewise, they were not particularly attracted to the prospect of constructing the Other within Europe itself. In the eyes of Russians who had looked to the West for reformist inspiration since the mid-nineteenth century, German or Austrian POWs were unlikely to become Others overnight. Furthermore, since Russian imperial territory was viewed simultaneously as Europe and Asia, Empire and nationstate, military anthropologists dealt simultaneously with "European" and "non-European" peoples of Russia, some of whom were termed "inorodtsy" ("aliens")-an official category for the non-Russian peoples often constructed by definition as inferior to the Russian population. ${ }^{21}$

19 The Commission for the Study of the Natural Productive Forces of Russia (KEPS) was established in May 1915 with the funding from the War and Naval Ministries; the committee to study the population of Russia (KIPS) was established in February 1916 within the Academy of Sciences of the USSR. See Dmitrii Nikolaevitch Anuchin, "Izuchenie proizvoditel'nykh sil Rossii," Zemlevedenie 23, nos. 1-2 (1916): 97-103.

20 For more, see Andrew D. Evans, "Anthropology at War: Racial Studies of POWs during World War I" in Wordly Provincialism: German Anthropology in the Age of Empire, eds. H. Glenn Penny and Matti Bunzl (Ann Arbor, MI: University of Michigan Press, 2003), 198-229.

21 This specific character of the Russian Empire, compared to Western colonial empires, received its most general treatment in Dominic Lieven, Empire: The Russian Empire and its Rivals (New Haven, CT: Yale University Press, 2000). On inorodtsy, see the classic study from John W. Slocum, "Who, and When, Were the Inorodtsy? The Evolution of the Category of 'Aliens' in Imperial Russia," Russian Review 57, no. 2 (1998): 173-190. 
The war became the moment of truth for Russian military anthropology in one sense only: It exposed its limits as the only state-sanctioned anthropological paradigm in Russia. To understand what happened, we need to look more thoroughly at how anthropology in uniform functioned in the decades immediately preceding the war.

\section{The Military-Medical Academy}

Russian military anthropology arose with reforms of the 1860s and 1870s that aimed at modernizing the Russian army. The military code of 1874 established the principle of universal all-soslovie [social estates] conscription. ${ }^{22}$ The War Minister Dmitrii Miliutin (1816-1912) figured as a reformer. Unlike the majority of civilian ministers, he saw the army as a modern institution fostering integration, including integration (with all de facto limitations) of the inorodtsy. ${ }^{23}$ To achieve this goal, Miliutin and the postreform general staff needed up-to-date population statistics and data on the "fitness" of the population. ${ }^{24}$ While the Interior Ministry continued to use religious confession as the main marker of difference, the War Ministry actively pursued geography, ethnography, and demographics. The reformist military became the conduit for the introduction of modern population policies and colonial discourses.

22 Ustav o voinskoi povinnosti, so vsemi dopolneniiami i raziasneniiami, posledovavshimi so vremen obnarodovaniia ego (St. Petersburg: Gogenfel'den, 1875).

23 On Muliutin's reforms in the army, see Petr Zaionchkovskii, Voennye reformy 1860-1870 godov v Rossii (Moscow: Moscow State University, 1952); Forrestt A. Miller, Dmitrii Miliutin and the Reform Era in Russia (Nashville, TN: Vanderbilt University Press, 1968); Beyrau, Militär und Gesellschaft; John L. Keep, Soldiers of the Tsar: Army and Society in Russia, 1562-1874 (Oxford: Clarendon Press, 1985); Bruce W. Lincoln, Nikolai Miliutin, and Enlightened Russian Bureaucrat (Newtonville, NJ: Oriental Research Partners, 1977).

On Miliutin's and the general staff officers' role in the development of Russian military statistics, see Carl Van Dyke, Russian Imperial Military Doctrine and Education (New York: Greenwood, 1990); David Rich, The Tsar's Colonels: Professionalism, Strategy, and Subversion in Late Imperial Russia (Cambridge, MA: Harvard University Press, 1998); idem, "Imperialism, Reform, and Strategy: Russian Military Statistics, 1840-1880," Slavonic and East European Review 74, no. 4 (1996): 621-639; Nikolai A. Mashkin, Vysshaia voennaia shkola v Rossiiskoi imperii (Moscow: Academia, 1997); Peter Holquist, "To Count, to Extract and to Exterminate: Population Statistics and Population Politics in Late Imperial and Soviet Russia," in A State of Nations: Empire and Nation-Making in the Age of Lenin and Stalin, eds. Ronald Grigor Suny and Terry Martin (Oxford: Oxford University Press, 2001), 110-143. 
The underlying logic of modernist reforms was once summarized by Peter Holquist in a memorable formula: "to count, to extract and to exterminate." 25 The phrase implies a colonial knowledge-power relation and is intended to explain pre-World War I and wartime deportations and manipulations of groups viewed by military scholars and officers as unreliable or "unfit." But in the case of Russian military anthropology, the teleological explanation is inadequate. As an autonomous client of military population statistics, it explicitly resisted colonial approaches in whose internal dynamic a census leads inevitably to mass murder. Though inspired by Western notions of the homogeneous national army as the core of a healthy national organism, Russian military anthropology was also strongly influenced by Moscow liberal anthropology's preoccupation with imperial diversity. General Staff Academy graduates and cadets had been exposed to colonial (i.e., western European) ideologies and techniques, but the military anthropologists, graduates of the St. Petersburg Military-Medical Academy (MMA), thought in terms of constructive social policy and the improvement of medical and sanitary conditions. They did not shrink from the task of redefining the imperial population in terms of relative "fitness." But their aim, rather than to "conquer" the Empire, was to bring the army into agreement with it-that is, to suggest a model that would rationally utilize the Empire's existing supply of "physical types."

In March of 1893, a group of MMA professors applied for permission to found an anthropological society, the first scholarly association in the academy's history. They were joined by high-ranking military officials including Chief Military-Medical Inspector Adolf Remmert, Chief Navy Medical Inspector Vladimir Kudrin, MMA Chancellor Viktor Pashutin, and a group of nonacademic anthropologists including criminal anthropologists such as Praskov'ia Tarnovskaia and the director of the St. Petersburg Anthropometric Station, Colonel Nikolay Kozlov. The application included standardized by-laws modeled on the statutes of the Moscow and St. Petersburg Anthropological Societies, ${ }^{26}$ and a rather informal letter explaining how anthropology was understood by the founders of the Society. The letter described aspirations to join the ranks of the anthropological movement in "civilized countries" at a stage when anthropology was ceasing to be an abstract science and becoming an empirical field to which physicians, linguists, and archaeologists, lawmakers and attorneys could turn for practical knowledge and

25 Ibid.

26 "Ustav Antropologicheskogo Obshchestva pri Imperatorskoi Voenno-Meditsinskoi academii," Trudy Antropologicheskogo Obshchestva pri IVMA za 1893 god 1, no. 1 (1894): 5-10. As a separate edition, see Ustav Antropologicheskogo Obshchestva pri Imperatorskoi Voenno-Meditsinskoi academii (St. Petersburg: Tipografia V. S. Ettingera, 1893). 
advice. ${ }^{27}$ It framed the goals of Russian anthropology in the language of the Moscow school, seeing its advantage in access to a uniquely diverse population on contiguous territory within a single polity.

Inspired by the example of the Moscow Anthropological Division, the founders of the MMA Anthropological Society wanted it to become a national centre for practical medical anthropology. The specific tasks of military anthropology were inscribed into this general agenda: Anthropology belonged in the tool kit of every physician. Doctors should gather objective knowledge about different groups within the imperial population and work on issues of special interest to the War and Naval Ministries. For the signatories, the connection between the study of "physical characteristics" of different peoples and the "interests" of military reformers was self-evident. ${ }^{28}$ While emphasizing the tradition of military professionals' participation in overseas expeditions and in the studies of inorodtsy in remote imperial borderlands, the MMA initiative would not carry forward the tradition of "exotic studies." Its aim was to normalize physical anthropology by making it a required topic in medical military training and the basis for a rational reorganization of the army. The charter received prompt approval from the War Ministry, and, by April 25, 1893, the MMA Anthropological Society was officially registered. The Academy held an opening ceremony in its assembly hall, broadly publicizing the event to demonstrate support for the new endeavor, ${ }^{29}$ and its leading professor of anatomy and later chancellor, Alexander Ivanovitch Tarenetskii (1845-1905), was elected chairman. ${ }^{30}$

27 "Vvedenie," Trudy Antropologicheskogo Obshchestva pri IVMA za 1893 god 1, no. 1 (1894): 1-4.

28 Ibid., 3-4.

29 "Otkrytie," Trudy Antropologicheskogo Obshchestva pri IVMA za 1893 god 1, no. 1 (1894): 13-14.

30 His anthropological works included Alexander Ivanovitch Tarenetskii, "Beiträge zur Craniologie der Ainos auf Sachalin," Mémoires de l'Académie Impériale des Sciences de Saint-Pétersbourg: VII-e sér XXXVII, no. 13 (1890): 1-55; idem, "Weitere Beiträge zur Craniologie der Bewohner von Sachalin-Aino, Giljaken und Oroken," Mémoires de l'Académie Impériale des Sciences de Saint-Pétersbourg: VII-e sér XLI, no. 5 (1893): 1-45; idem, "Beiträge zur Skelett- und Schädelkunde der Aleuten, Konaegen, Kenai und Koljuschen mit vergleichend anthropologischen Bemerkungen," Mémoires de l'Académie Impériale des Sciences de Saint-Pétersbourg: VII-e sér IX, no. 4 (1900): 1-73, etc. For a full bibliography of Tarenetskii's work, see in "Pamiati A. I. Tarenetskogo," Voenno-Meditsinskii zhurnal 3 (1905):899-904. About his life, see A. Ivanovskii, "A. I. Tarenetskii: Nekrolog," Russkii Antropologicheskii Zhurnal XXIII-XXIV, nos. 3-4 (1905): 214-217; [D. Anuchin?], "A. I. Tarenetskii (Nekrolog)," Russkie Vedomosti, November 6, 1905, 3; Professora voenno-meditsinskoi (medikokhiryrgicheskoi) academii 1798-1998 (St. Petersburg: Nauka, 1998). 
Anthropology, especially applied anthropology, had never enjoyed such prominent recognition and support from any Russian academic institution, military or civilian. It became a widely accepted, quasi-mandatory method of assessing conscripts, who were viewed as bearers of national-racial characteristics. Tarenetskii's own method-armchair craniology $y^{31}$ - proved a poor model, but he should be credited with fostering an atmosphere that encouraged enthusiasts of anthropology to devise research projects and develop them into dissertations. In his obituary in the Russian Anthropological Journal, Tarenetskii's image as a scholar and anthropologist is clearly overshadowed by his reputation as a supervisor of numerous dissertations defended at the MMA. $^{32}$

The real ideologist of the MMA Anthropological Society was Dmitrii Petrovitch Nikol'skii, himself a graduate of the Academy, a sanitary doctor and anthropologist who studied both ethnic (inorodtsy) and social (workers, women) subaltern groups. He was also a popular activist of socialist convictions. ${ }^{33}$ It was Nikol'skii, not Tarenetskii, who gave the first programmatic presentation in the Society on November 22, 1893. His characterization of the field of anthropology was unusually broad: A study of imperial diversity

31 Tarenetskii studied skulls of the inorodtsy since they were present in the museum collections accessible to him, and due to his personal interest in the genesis of the "Indian" type. However, when he had a chance, he studied the "Great Russian" skulls with a similar zeal. See, for example: Alexander Ivanovitch Tarenetskii, "Beiträge zur Craniologie der grossrussischen Bevölkerung der nördlichen und mittleren Couvernes des Europäischen Russlands," Mémoires de l'Académie Impériale des Sciences de SaintPétersbourg: VII-e sér XXXII, no. 13 (1884). He did not personally participate in the expeditions that involved the study of a living population, however, for his students and the MMA Anthropological Society's members, he developed and published instructions on how to take measurements on live subjects. See idem, Neskol'ko zamechanii po povodu antropologicheskikh issledovanii na zhivykh (St. Petersburg: Military-Medical Academy, 1889); idem, $K$ voprosu ob izmereniiakh cherepa i mozga (St. Petersburg: Military-Medical Academy, 1884).

32 His program was included in the text of the article, idem, "Neskol'ko zamechanii po povodu antropologicheskikh issledovanii na zhivykh," Vrach 3 (1989): 45-46.

33 On his life and work, see "O sluzhbe privat-dotsenta D. P. Nikol'skogo," TsGIA SPb. F. 436. D. 14480. Op. 1, Vol. 2. (1913). 22 LI., esp. 9-11; "Doklad komissii po razboru trudov d-ra med. D. P. Nikol'skogo, ischuschego zvaniia privat Dotsenta gigieny pri SPb. Zhenskom Meditsinskom institute," TsGIA SPb. F. 436. D. 14480. Op. 1, Vol. 2. LI. 2-8 rev.; "Obzor rabot po antropologii v sviazi s meditsinoi, predstavlennykh Dr. Nikol'skim k soiskaniiu zvaniia privatdotsenta SPb. Zhenskogo Meditsinskogo institua po kafedre gigieny," TsGIA SPb. F. 436. Op. 1. D. 14480, Vol. 2. LI. 4-6 rev. 
on the Moscow liberal model, ${ }^{34}$ it included "anthropological-ethnographical, craniological, medical-anthropological (with demography), and anthropometrical" research. ${ }^{35}$ The practical orientation of MMA faculty was evident in their respectful treatment of Russian physicians, lawyers, and intellectuals who were followers of the Italian founder of criminal anthropology Cesare Lombroso, ${ }^{36}$ whereas other learned societies were critical of criminal anthropology. Nikol'skii, however, established a synthesis of traditional academic anthropology and its applied forms, medical-sanitary anthropology. ${ }^{37}$

Prewar Russian society had only limited concern for social hygiene. MMA scholarship primed the eventual wartime and postwar mobilization of state and society around the problem of the healthy individual and national body, ${ }^{38}$ although its wartime role was limited. Unlike the Moscow Anthropological Division, a think tank with its own financial and institutional resources and research agenda, the MMA Anthropological Society was an association of individuals, unable to function without military physicians, who attended the Academy for three years and wrote dissertations under the tutelage of MMA professors. It was these practitioners of applied military anthropology, and not the Society's Petersburg-based founders, who collectively shaped its agenda in accordance with directives and ideological messages coming from the War Ministry and its main Military-Sanitary Administration. The structural constraints became apparent during the Russian-Japanese War (1904-1905). When the army doctors- "major presenters at our meetings," as the Society's

34 Nikol'skii chose to open his presentation with a detailed overview of the publications of the Moscow Anthropological Division.

35 D. P. Nikol'skii, "Obzor russkikh rabot po antropologii za posledniie tri goda," Trudy Antropologicheskogo Obshchestva pri IVMA za 1893 god I, no. 1 (1894): 107. Ibid., 123-131.

37 Ibid., 138.

38 In accordance with such a broad understanding of anthropology, presentations given at the Society's meetings ranged from the "classical" anthropology of imperial diversity, for example, Ju. D. Tal'ko-Hryntsevitch, "On anthropology of the peoples of Lithvenia and Belorussia (Protokol zasedania 20 dekabria 1893 g.)," Trudy Antropologicheskogo Obshchestva pri IVMA za 1893 god I, no. 1 (1894): 155-187; to ethnographic studies, Vladimir Bogoraz, "O chukchakh kolymskogo okruga (Protokol zasedaniia 24 janvaria 1900 g.)," Trudy Antropologicheskogo Obshchestva pri IVMA za 1899-1900 uchebn. goda VI (1903): 31-47; from craniology, Alexander Ivanovitch Tarenetskii, "Posmertnye povrezhdeniia cherepa (Protokol zasedaniia 27 sentiabria 1893.)," Trudy Antropologicheskogo Obshchestva pri IVMA za 1893 god I, no. 1 (1894): 19-24; to criminal anthropology, A. L. Marshand, "Nekotorye nabliudeniia nad det'mi prestupnikov (Protokol zasedania 24 fevralia 1897 g.)," Trudy Antropologicheskogo Obshchestva pri IVMA za 1896-97 god IV, no. 1 (1899): 122-152. 
secretary K. Yatsuta put it ${ }^{39}$-left for the front, the Society suspended its activities. ${ }^{40}$ The same happened during the Great War.

\section{The Army as Empire}

The MMA library holds a collection of dissertations defended in the Academy. They represent only the tip of the military-medical-anthropological iceberg, but they suggest the scale of the anthropological work conducted in the Russian army in the prewar years. ${ }^{41}$ Although anthropological theses never exceeded seven percent of all MMA dissertations (the percentage varies from year to year), given the absence of a tradition of academic anthropological scholarship and the modest number of anthropological dissertations defended in Russian universities, this can be regarded as an impressive percentage.

A review of anthropological dissertations defended at the MMA from 1882 to $1913^{42}$ testifies to the limited appeal of colonial-style anthropology. Only a few projects feature the uniformed scientist armed with his own civilization's superiority passing judgment on a non-Russian population in terms of their inherent inferiority. Yet, even the few theses taking an explicit "colonialist" approach were heavily influenced by the liberal discourse of imperial diversity. A case in point is the dissertation by Nikolai Vasil'evitch Gil'chenko, M.D., who, after leaving the MMA, served in the Caucasus at the Vladikavkaz military hospital. ${ }^{43} \mathrm{He}$ had total control over soldiers' cadavers as well as the organs of deceased local residents as it was the region's only medical facility. Gil'chenko exploited the advantages of his position in the hospital to study human difference, if only post mortem. His situation allowed him to practice the most technologically complex type of anthropology, which had developed mostly outside Europe in remote colonies and on a limited scale: the study of the brains of "living people" (i. e., not centuries old), or, as was said at the time, "fresh brains." The discipline required immediate and unrestricted access.

39 K. Yatsuta, "Ot redaktora," Trudy Antropologicheskogo Obshchestva pri IVMA za 1901-1904 uch. goda VII (1912): 3.

40 Because of the revolutionary events, the pause lasted until the end of 1906.

41 Spisok dissertatsii, izdannykh Voenno-Meditsinskoi Akademiei (a typewritten copy). Fundamental library of the MMA named after S. M. Kirov; E. S. Viaz'menskii, Dissertatsii VMOLA (half typewritten and half handwritten copy). Fundamental library of the MMA named after S. M. Kirov. I am indebted to the librarians for letting me work with these archival catalogues.

42 See Mogilner, Homo Imperii.

43 For his biography see Curriculum vitae attached to the dissertation Nikolai Vasil'evitch Gil'chenko, "Materialy dlia antropologii Kavkaza. I. Osetiny" (PhD thesis, Imperial Military-Medical Academy, 1890), 216-217. 
With industrial efficiency, Gil'chenko extracted, prepared, and weighed the brains of peoples including Great Russians, Little Russians, other Slavic soldiers as well as the mountain-dwelling inorodtsy of the Caucasus. ${ }^{44}$ Although formally a doctoral student of Tarenetskii, Gil'chenko turned to the Moscow Anthropological Division for methodological guidance; by including the Caucasian brains, his unprecedented (in terms of actual number of brains weighed) research extended beyond those brains customarily included in the contested construct of the "big Russian nation."

He also calculated the median and average "brain of the Empire." ${ }^{45}$ Gil'chenko took issue with devotees of Lombroso by defending his right to include the brains of Chechen "criminals." He insisted that they were criminals only from the Russian point of view, while, in the context of their own culture, they were its best representatives, embodying native notions of dignity, brotherhood, and justice. ${ }^{46}$ They were neither atavisms nor deviants who had to be isolated from a civilized, normative, and healthy social body, but "normal" or even high-quality physical elements of the imperial organism. He openly rejected correlations between brain weight and intellectual faculty. He did so the more easily, the less his findings confirmed racist stereotypes; the brains of Russians in his collection proved to be the lightest, while the brains of the inorodtsy were heaviest. ${ }^{47}$ Women's brains were disregarded as a priori lighter, with 40 measurements produced in support.

44 Idem, "Ves golovnogo mozga i nekotorykh ego chastei u razlichnykh plemen naseliauschikh Rossiiu," Izvestiia IOLEAE (Trudy Antropologicheskogo otdela XIX) XC (1899): 167-219. For similar examples of military anthropological research, see I. Bukhshtab, "Materily k voprosu o vese, ob'eme i udel'nom vese golovnogo mozga u sub'ektov oboego pola i raznogo vozrasta: Takzhe o razmerakh cherepa i naruzhnoi poverkhnosti dolei mozga" (PhD thesis, Imperial Military-Medical Academy, 1884); see also a published version of the presentation by the military doctor F. A. Birulia-Belynitskii at the meeting of the MMA Anthropological Society containing the results of his study of 336 brain samples. F. A. Birulia-Belynitskii, "K voprosu o vese mozga: Materialy dlia antropologii slavianskikh narodnostei Rossii; Doklad na zasedanii 9 janvaria 1895 g.," Vrach 3 (1895): 14-32.

45 The median "imperial brain" combined data for 221 Great Russian brains, 133 Little Russian brains, 90 brains of the undetermined "Russians" from the Caucasus, Don region, and western borderlands of the Empire; 102 Polish brains, 7 Lithuanian, 16 German, 23 Jewish, 3 Estonian, 8 Votiak, 1 Permiak, 16 Zyriane, 2 Mordva, 7 Cheremis, 9 Chuvash, 9 Tatar, 11 Bashkir, 11 Osetian, 17 Chechen, 1 Cirkassian, 3 Dagestani, 11 Georgian, and 12 Armenian brains.

46 Gil'chenko, "Ves golovnogo mozga i nekotorykh ego chaste," 107.

47 The Russian brain was the lightest in the Empire (1,367.9 gr.), while the Russian average height index corresponded to the general height calculated for the 
Studies in "military-sanitary anthropology" generally focused on discussions of a new kind of army, reassessing national-ethnic strata and reassigning ideological semantics to physical characteristics. In the 1910s, there was concern that the army was in need of optimization before it could handle the new style of warfare that military leadership now anticipated. Working on a project conceivable only within the structural framework of military anthropology, but thinking in terms of the liberal anthropology of imperial diversity, Gil'chenko was prepared to find arguments in favor of noncoercive, objectively justified integration of imperial subjects, rather than colonial hierarchies. With such a pragmatic focus-a modern army - the female becomes an Other of sorts, somewhat in defiance of the reformist feminism of the MMA Anthropological Society's founders. ${ }^{48}$

\section{Ethnic Fitness}

While religion remained a prevailing official category of difference, in the MMA's military-sanitary anthropological dissertations, ethnically neutral categories, such as "recruit" and "healthy soldier," ${ }^{49}$ were forced out by notions of the soldier as a bearer of national or racial characteristics.

whole imperial population. To imagine the scale of a problem, consider the weight of the "Ossetian brain" which was calculated as 1,465.5 gr.

The feminist trend in Russian anthropology stressed the importance of the study of female bodies, posited woman as a more "pure" bearer of a racial type, and rejected female racial inferiority. This trend coexisted with an "orientalizing" trend that assumed females were racially inferior. As examples of the latter, see V. V. Vorob'ev, "Neskol'ko dannykh po antropologii velikorusskoi zhenschiny," Russkii Antropologicheskii Zhurnal 3-4 (1903): 9-16; E. Chepurkovskii, "K antropologii Russkikh zhenschin," Russkii Antropologicheskii Zhurnal 2 (1903): 13-23. As the example of the former approach, see the criminal-anthropological research by Praskov'ia Tarnovskaia, who constructed both Russian national "deviation" and Russian national "norm" on the basis of female anthropometrical data, P. N. Tarnovskaia, Zhenschinyubiitsy: Antropologicheskoe issledovanie s 163 risunkami i 8 antropometricheskimi tablit-sami (St. Petersburg: Tovarischestvo Khudozhestvennoi pechati, 1902). About discourse on race as a possible code of gender differences, see Nancy Leys Stepan, "Race and Gender: The Role of Analogy in Science," Isis 77 (1986): 261-277.

49 As an example of the usage of this category, see V. Baulin, "Materialy k izmereniam u zdorovykh soldat rosta, vesa, ob'ema grudi, zhiznennoi sily legkikh, sily ruchnykh kistei vmeste i sily pod'ema" (PhD thesis, Imperial MilitaryMedical Academy, 1889). While using the notion of a "healthy soldier", Baulin does not indicate his nationality or confession and provides only very insufficient data on the region from where each "healthy soldier" was drafted. 
As an emerging academic and public concept predicated on language and customs, ethnicity stood in the way of the blending of distinct groups in a single national body. For example, it distinguished Great Russians from Little Russians and White Russians (roughly corresponding to today's Russians, Ukrainians and Belorussians) instead of labeling them, cumulatively, "Russians." The trend to nationality and race was a radical novelty that had begun with the introduction in 1887 of a mandatory "medical form" [meditsinskii listok] on file for each recruit. It recorded confession, social origin, occupation, and physical characteristics such as height, weight, chest circumference, and leg length, but not nationality. ${ }^{50}$ Previously, as of 1869 , body weight and chest circumference had been the major criteria of fitness for military service. The latter indicator roused many debates in the military-medical community and was not considered universal. The same could be said for weight, which ceased to be a crucial indicator of fitness in $1875 .^{51}$

The new medical form drew on the experience of physical anthropology, which operated not in absolute terms but on a relational system. Beginning in 1887, it was no longer body weight, chest circumference, or height that determined "fitness," but such proportions as the ratio of chest circumference to the half-height index. ${ }^{52}$ Obviously, a physician filling in such a form was expected to know the basics of anthropometry, sensitizing him to anthropological thinking in general. The forms constructed each soldier as a "physical element" representing larger social (confessional, social estate) and physical (racial) collectives. Medical forms became a font of anthropometric data, with no analogue in nonmilitary anthropology. The medical form accompanied the soldier through his years of army service, documenting his medical history within a multinational collective.

The medical forms of soldiers recognized as "unfit" were appended to the monthly reports of garrison physicians and forwarded to the main Military-

50 The form is reproduced in P. G. Avramov, "Materialy po voenno-meditsinskoi statistike: Opyt razrabotki 'meditsinskikh listov'"' (PhD thesis, Imperial Military-Medical Academy, 1895), 5-6.

51 For more on the problems of using weight as a criteria of "fitness," see N. I. Oranskii, "K voprosu o znachenii vesa tela, kak dopolnitel'nogo kriteriia k tsifram grudi i rosta u novobrantsev (po dannym meditsinskikh listov): Po materialam Glavnogo Voenno-Sanitarnogo upravleniia" (PhD thesis, Imperial Military-Medical Academy, 1911).

52 See, for example, in Avramov's dissertation the discussion pertaining to the determining of degree of physical development on the basis of ratio of chest circumference to a half-height index. See idem, "Materialy po voenno-meditsinskoi statistike," 73-74; see also a systemic approach as expressed in the very title of the dissertation by Oranskii "K voprosu o znachenii vesa tela" and many other examples. 
Sanitary Administration in St. Petersburg to be filed in its archives. Thus, information about the Empire's physically "unfit" population accumulated centrally. Due to the form's format, physical and medical data were automatically associated with confession, name, and place of birth. Given the persistence of "premodern," mostly religious, categories of ethnic and social difference in official Russian statistics, ${ }^{53}$ only the combination of those data permitted the extraction, or rather construction, of "nationality."

Anthropologists were disturbed by the absence of the category of "nationality" in military documents. As Ivan Mikhnevich, a junior physician in the 79th Infantry Kurinsky Regiment, wrote in his dissertation:

In the medical forms, there are entries for the province [gubernia] and district [uezd], but there is no entry for nationality. For those cases where religion coincides with nationality, we can easily solve the problem of nationality of each new recruit. Yet in the majority of cases we have to base our conclusions about nationality on a combination of the province of origin [gubernia] with religion, risking a greater margin of error. ${ }^{54}$

On April 20, 1898, the MMA Anthropological Society gathered to discuss Dr. Nikol'skii's presentation on a minority of the Volga region, the Teptiars, regarded by both scholars and the state as a distinct ethnic group. Originally a social estate that included ethnic Tatars, Mari, and other peoples of the Volga, they had, in the course of their existence, developed a distinctive cultural identity. Nikol'skii based his conclusions on a very limited number of anthropometric measurements, but, nonetheless, Society members resolved to propose a revision of the religious-ethnic nomenclature used in the "medical forms" in which all Muslim inorodtsy were identified as ethnic Tatars. Thus Nikol'skii's somewhat dubious attempt to establish a Teptiar "type" was greeted by his fellow anthropologists as proof of Teptiar "nationality." By hook or by crook, nationality came to play a role in military statistics. ${ }^{55}$

53 On the categories of social difference, see Gregory Freeze, "The Soslovie [Social Estate] Paradigm and Russian Social History," The American Historical Review 91, no. 1 (1986): 11-36.

54 Ivan I. Mikhnevitch, "Uvolennye po protestu novobrantsy prizyvov 18951898 gg." (PhD thesis, Imperial Military-Medical Academy, 1900), 14-15. See also his "Meditsinskie listy v kachestve statisticheskogo materiala. Opyt statisticheskoi razrabotki meditsinskikh listov pekhotnoi divizii za tri sroka sluzhby," Voenno-Meditsinskii zhurnal IV (1899): 13-21.

55 "Protokol zasedaniia 20 aprelia 1898 g.," Trudy Antropologicheskogo Obshchestva pri IVMA za 1897-1899 uchebn. goda V (1901): 96. Nikol'skii's colleagues argued that, since "the number of the examined persons exceeded 11," his conclusions were quite precise. 
Why did military anthropologists decry the absence of "nationality"? At the end of the 1880s, even as they obsessively synthesized nationalities from surnames, confessions, and regions, official imperial statistics made do with religion and occasionally ethnicity, both understood as cultural categories. ${ }^{56}$ It is a remarkable fact that the state-run Herald of Popular Hygiene, Forensic and Practical Medicine published military statistics purged of religious-not to mention ethnic-categories. ${ }^{57}$ In such a presentation, the Russian Empire appears as an a-national state. This bothered Russian imperial military anthropologists. In their quest for a modern, efficient army, they looked to European nation-states whose armies were formed on the principle of universal conscription. The trend dated back to Miliutin's reforms and was reinforced by his military statistician followers through their continually escalating criticism of the Empire's poor population management. Holquist very appropriately quotes a textbook for students of the General Staff Academy by A. M. Zolotariev (1885), who contrasted the loyal and homogenous populations of the Moscow military district and the Île-de-France with the heterogeneous, ethnically diverse, unreliable populations of the Caucasus and British India. ${ }^{58}$ Naturally, in this context, it was the category of nation, and not religion, that would permit comparison of Russian and Western realities.

The MMA Anthropological Society's reaction to Nikol'skii's presentation reveals an aspect of "nationality" that was even more important to Russian military anthropologists. While both "religion" and "ethnicity" were seen as outdated, irrational cultural categories, "nation" and "race" represented modern, verifiable categories of scientific discourse - an attitude that strongly suggested race as a basis for sorting out nationality. In other words, a nation might be constructed from a unitary and congenital physical type, traceable to each individual member of a given collective. This represented a major deviation

56 On the religious category of difference in Imperial Russia, see Robert Crews, "Empire and the Confessional State: Islam and Religious Politics in Nineteenth-Century Russia," The American Historical Review 108, no. 1 (2003): $50-83$.

57 See "Otchet Glavnogo Voenno-Meditsinskogo Upravleniia za 1897 god", adapted for publication under the title "Boleznennost', smertnost'i uvol'neniie v nesposobnye v Russkoi armii za 1897 god," Vestnik Obshchestvennoi gigieny, sudebnoi i prakticheskoi meditsiny 9 (1899): 93-96. Here, the neutral term "lower-rank personnel" is used, while statistics are organized according to the arm of the service and the type of illness.

58 This example quotes Peter Holquist in "Total'naia mobilizatsia i politika naseleniia: Rosi-iskaia katastrofa (1914-1921) v evropeiskom kontekste," in Rossiia i Pervaia mirovaiia voina, Materialy mezhdunarodnogo nauchnogo kollokviuma, eds. N. N. Smirnov, Z. Galili, R. Zelnik et al. (St. Petersburg: Dmitrii Bulanin, 1999), 85. 
from the Moscow liberal paradigm that insisted on a fundamental differentiation between race and nation, stressing the unscientific nature of speculations connecting "physical type" to abilities and physical and intellectual "fitness."

To further complicate the peculiarity of the military-anthropological discourse, its "nation-race" was not a purely biological category. Whatever "nation" supplied its "contingent" to the army was treated as a collective imperial subject and an object of social, economic, cultural, and political influence. Thus, the discourse often appeared to be quite sensitive to the immediate social, historical, and cultural circumstances of a group's existence in a particular territory. ${ }^{59}$ This difference was especially evident in the case of Jews. Official military statistics constructed them as poor citizens who would do anything to evade conscription. ${ }^{60}$ Military anthropologists performing measurements and calculations and working with the new medical forms were more willing to recognize such factors as the high mobility of the Jewish population and its predominantly urban makeup. Cities everywhere in the Empire, including highly urbanized regions such as Poland with its substantial Jewish population, consistently produced the greatest numbers of physically weak recruits as well as those who did not wish to serve. ${ }^{61}$ Attentive to the local environment and conditions, the anthropologists tended to regard ethnic and confessional groups-whether "Russian" or inorodtsy-as "nations," modernizing the representation and elevating the status of groups whose men were eligible for military service. Yet, such outcomes had nothing to do with liberal ideology or a desire on the part of the War Ministry to introduce universal conscription. Military anthropologists appeared to be vanguard "nationalists," because they embraced the race-nation dogma and because their practical goal was to lay the foundation for rational implementation of intrinsic national differences in one supranational military body.

59 This distinguished Russian military anthropology from the "a-social" approach of many works by leading Russian military statisticians, such as Alexander M. Zolotariev. See idem, "Materily po voennoi statistike Rossii: Boleznennost', smertnost' i ubyl' armii za period 1869-1884 gg.," Voennyi sbornik 2 (1888): 323-341; ibid., 3 (1888): 177-193; ibid., 4 (1888): 351-365; ibid., 11 (1888): 157-176; idem, "Materily po voennoi statistike Rossii: Naseleniie Rossii kak istochnik komplektovaniia ee armii," Voennyi sbornik 5 (1889): 98-141; ibid., 6 (1889): 334-359.

60 For an exhausting analysis of the military statistics on Jews, see Yohanan Petrovkii-Shtern, Evrei v Russkoi armii: 1827-1914 (Moscow: Novoe Literaturnoe Obozrenie, 2003), Ch. IV.

61 Moscow, for example, persistently supplied a high percentage of weak soldiers, many of whom were recognized as "unfit" for military service. In 1882, their number made up to 69 percent of all recruits. See I. V. Gessen, Voina $i$ evrei (St. Petersburg: Tipografia Stasulevicha, 1912), 97-100. 
In military anthropology, dissertations defended roughly before the period of normalization and reaction that followed the Revolution of 1905-1907 perceived the dynamic coexistence of biologically, psychologically, and socially different collectives within the Empire rather positively. However, this changed with the postrevolutionary political demobilization. On the eve of the Great War, the metaphor of the army as a modernized Empire acquired more negative connotations. A close reading of two dissertations typical for their time should elucidate this dramatic rupture in the history of Russian military anthropology.

\section{Extracting Nationality}

Mikhnevich, who defended his dissertation in 1900, proceeded from the assumption that foreign armies were radically unlike the Russian army. Foreign armies were biologically homogeneous, drawing contingents from comparatively small territories. The district of conscription tended to coincide with the area of service, with soldiers typically serving in familiar surroundings among people who shared their religion, language, and customs. ${ }^{62}$ One-fourth of the Russian army, on the contrary, was composed of inorodtsy; soldiers of different nationalities represented "contingents differing in a physical sense." They served in far-flung corners of a huge empire with an "absolutely new climate and population [for them]." ${ }^{63}$ The food regimen in the army was not "adapted" to existing national diversity: The standard menu could satisfy neither a northerner accustomed to rich food nor a native of the Caucasus unused to sour bread. The requirements of Jews posed problems, yet they were comparable to those of soldiers from the mountains of the Caucasus (Imeretins and Mingrels). ${ }^{64}$ The issue of "adaptation," which in European pre-World War I anthropology usually meant the acclimatization of a European to a tropical environment, was reformulated by Mikhnevich as a domestic problem of central importance to the Russian army. The argument's colonial connotations faded. In the army, everyone, everywhere, had to "adapt."

62 Ivan I. Mikhnevich, "Uvolennye po protestu novobrantsy prizyvov 1895-1898 gg." (PhD thesis, Imperial Military-Medical Academy, 1900), 1-2. Quotations are given according to the published version of the analytical (as opposed to numbers and calculations) part of the dissertation: Idem, "Uvolennye po protestu novobrantsy 1895-1898 gg.," Voenno-Meditsinskii zhurnal 3 (1900): 848. Ibid.

64 Ibid., 890. Mingrels and Imeretins are subgroups of the Georgians who until the 1930s had their own census groupings (including the pre-1917 censuses). Their dietary habits included many herbs, spicy meals, and only unleavened bread. 
Each nationality drafted into the army was assigned certain innate physical traits, allowing Mikhnevich to rank the "fitness" of various race-nations. None were categorized as "harmful" or "organically unfit"; Mikhnevich never forgot his central goal of easing cooperation among unequal nations. Study of their physical peculiarities would allow him to explain (with racial, environmental, or other factors) and manipulate them. His approach questioned the universal applicability of the physical criteria of "fitness." It differed, in principle, from the exceptions introduced by the Interior Ministry for Jews, who could be drafted even when they failed to meet fitness standards. ${ }^{65}$ As Mikhnevich explained in his dissertation, since the nation-races of the Empire were anthropologically different, criteria could not be universal: They must incorporate the entire spectrum of extant differences. He specifically addresses the issue of height, considered by turn-of-the-century anthropology to be a marker of race- a view endorsed by Russia's most prominent anthropologist, Anuchin, who authored a classic study of the height index's distribution among the male population of Russia. ${ }^{66}$ Mikhnevich proposed that norms be revised to reflect the Empire's diversity.

The farther north a province lies, the greater the percentage of short people among its population; the highest percentage of short people are provided by Kazan, Ufa and Viatka provinces [gubernii]-more than $20 \%$ of all drafted to the army. ${ }^{67}$

According to Mikhnevich, race had to be taken seriously, both as a basis for flexible "fitness" criteria and as a governing principle for appropriate deployment of soldiers to produce a strong, resilient, and competitive modern army.

To prove the validity of his analysis, Mikhnevich turned to the medical forms in search of "nation-race." He easily found this in Jews whose ethnicity and religion coincided and in Armenian Orthodox and CatholicsMikhnevich combined them into a single Armenian nation. ${ }^{68}$ But that was the

65 Between 1880 and 1881, the Ministry of Internal Affairs introduced the whole range of police measures aimed at preventing "Jewish evasion" of military service. The Minister of Interior, Dmitrii Tolstoi, among other things, ordered to draft Jews whose chest circumference was smaller than the officially accepted measurement. In general, military medical commissions could legally violate established standards of fitness when they examined Jewish recruits. Petrovkii-Shtern, "Evrei v russkoi armii," 189.

Dmitrii Nikolaevitch Anuchin, "O geograficheskom raspredelenii rosta muzhskogo naseleniia Rossii (po dannym o vseobschei voinskoi povinnosti v Imperii za 1874-1883 gg.) sravnitel'no s raspredeleniem rosta v drugih stranakh," Zapiski Imperatorskogo Russkogo Geograficheskogo Obshchestva po otdeleniiu statistiki VII, no. 1 (1889).

67 Mikhnevich, "Uvolennye po protestu novobrantsy 1895-1898 gg.," 899.

68 Ibid., 851. 
end of the easy cases, where nationality followed from religion. Mikhnevich considered Orthodox Christians "predominantly Russian," a nation that integrated Great Russians, Little Russians, and White Russians with Old Believers and Dissenters. Military and civil statistics treated the latter two groups as distinct from "Russians," ${ }^{\prime}$ but the logic of assembling a nation from archaic categories that fragmented the organic national whole necessitated the return of religious dissidents into the national body. The nationalization of "Orthodox Christians" on the medical forms was further complicated by the fact that "Russians" made up only 76.4 percent of that group, with the rest composed of Moldavians, Georgians, Greeks, South Slavs, and Finnish peoples of the Volga and Ural regions. Complications were common. Splitting Roman Catholics into two large national groups, Poles and Lithuanians, left the German Catholics of Saratov and Samara unaccounted for. Protestants could be "nationalized" as Germans, Estonians, or Latvians.

To solve such problems, Mikhnevich introduced an additional variable: territory. Ignoring the existing system of provinces and districts, including military districts, he introduced sixteen regions with more or less ethnically and religiously homogeneous populations. ${ }^{70}$ Great Russians, Moldavians, Germans, Lithuanians and other collectives studied by Mikhnevich were assigned national territories along with their national status. To eyes schooled in nationalism, such a remapping is highly suggestive, but Mikhnevich apparently did not see the political implications of his approach. He was merely doing his best to extract nationality from the medical forms in hope of establishing morbidity rates for nations supplying recruits to the army.

He concluded that there were no "sick" or "healthy" nations. Pagans, Jews, and Muslims were most frequently judged "unfit" due to eye problems; Armenians, Muslims, Protestants and Catholics produced the majority of recruits with neurological disorders. Very few neurological diseases were registered among Jews; yet they, together with Muslims, took the lead in chronic skin conditions. Mikhnevich's dissertation contains anti-Jewish and antiMuslim statements, in some cases as citations from the work of military statisticians, but they remain peripheral to the narrative, as they explicitly contradict his method and goal.

69 Irina Paert, "Two or Twenty Million?," Ab Imperio 7, no. 3 (2006): 75-98.

70 Mikhnevich, "Uvolennye po protestu novobrantsy 1895-1898 gg.," 852-853. This type of "cartography" that helped to tie down a population to a particular territory was practiced by almost all military anthropologists unsatisfied with the categories of official military statistics. Dr. Avramov, whose dissertation, like many others, was based on the medical forms, divided all of European Russia into seventeen climate zones and tied each to a particular group of the population. Idem, "Materily po voenno-meditsinskoi statistike," 61-62. 
To generate his taxonomy, Mikhnevich had to operate with the categories on the medical forms. However, he missed no opportunity to transpose them into the language of nationality that he had invented. The marginalization of actual soldiers diagnosed with particular diseases was a side effect of such manipulations. Their afflictions, no longer individual if not necessarily innate, became typical of race-nations that were populating the Russian army with deficient recruits, ${ }^{71}$ provoking scrutiny of the common causes of "degeneration"-not just of weaker elements, but of a population as a whole. Mikhnevich wrote:

All European Russian territories, excluding only the far north, gave a rather substantial percentage of unfit recruits. As we can see, the fact that these unfit recruits keep coming to the army depends on some general causes and is not characteristic to some particular territories. This is a very broad, common phenomenon. ${ }^{72}$

\section{Unequal Nations}

Racial traits, hereditary deficiencies, and the merits of potential "contingents" were the building blocks used by military anthropologists to construct their model of an ideal imperial army. Their construction work was guided by a rational logic of integration, rather than segregation and racial discrimination. Such an approach characterizes the majority of anthropological dissertations written under the tutelage of MMA professors before about 1907. Moreover, the integrationist agenda can be spotted even in military-medical works produced on the eve of World War I, under new political circumstances and in the context of the imperial elite's reorientation toward state-sponsored ethnic Russian nationalism.

Yet, despite the persistence of some liberal tropes and research methods, the 1910s saw a shift toward a more radical discourse of physical "unfitness" in Russian military anthropology. The shift was heavily influenced by the experiences of the Russian-Japanese War and the First Russian Revolution, as well as Duma debates that drew popular attention to the "national question" and its potentially dire political implications. The war of 1904-1905 unleashed anxieties over the "yellow peril," leading to the introduction of anti-Chinese and anti-Korean legislation. ${ }^{73}$ The mass revolutionary movement used national

71 Mikhnevich, "Uvolennye po protestu novobrantsy 1895-1898 gg.," 861-877.

72 lbid., 879.

73 See more in Lewis H. Siegelbaum, "Another 'Yellow Peril': Chinese Migrants in the Russian Far East and the Russian Reaction before 1917," Modern Asian Studies 12, no. 2 (1978): 307-330; regarding the "yellow peril" discourse on 
rhetoric, while increased press freedom led to a wide distribution of racist and ethnic images and stereotypes ${ }^{74}$ as well as nationalist programs. The April 1905 law on religious freedom legalized conversions, further exacerbating the existing fluidity of social, confessional, and ethnic boundaries. Politicians, government officials, and military and civil professionals became aware of the mobilizing power and dangers of nationalism.

As an applied technical science loyal to the state, military-medical anthropology experimented with categories of race and nation while remaining on the margins of the dominant political discourses. The situation changed when the army was officially reevaluated as an institution of the Russian national state. Non-Russian nationalism had begun to be seen as threatening the very survival of the Russian Empire. This was the time of the birth of a "new army anti-Semitism," in the words of Dietrich Beyrau. ${ }^{75}$ Military anthropology acquired a new scientific mission: to justify the cleansing of the Russian national military organism from elements that made it liable to "degeneration."

Finally, in October of 1909, the main Medical Corps administration issued directive No. 21221, authorizing "nationality" as a category on the medical forms. The military anthropological community had long awaited the canonization of nationality in military statistical discourse, but it came at a moment when the concept, with its racial implications, had already become a widespread-and semantically overloaded-category in Russian politics. When the MMA PhD candidate Mikhail Ivanovitch Gusev, a physician of the Eighth Military Corps, wrote his dissertation in 1910 ("An Experiment in the Study of Comparative Fitness for Military Service of Different Nationalities Composing the Russian Army"76), he was well aware of the implications of the new political situation. He drew on a previous tradition of military anthropological scholarship, citing Mikhnevich and other supporters of integration. He repeatedly complained about the absence of "nationality" in the pre-1909 medical forms and even reproduced some of the liberal tropes from earlier

the eve of the Russian-Japanese war, see David Schimmelpenninck van der Oye, toward the Rising Sun: Russian Ideologies of Empire and the Path to War with Japan (Dekalb, III: Northern Illinois Press, 2001).

74 This was especially true of anti-Semitic images and stereotypes. See HeinzDietrich Löwe, "Political Symbols and Rituals of the Russian Radical Right, 1900-1914," Slavonic and East European Review 76, no. 3 (1998): 441-466. See also D. A. Kotsubinskii, Russkii natsionalizm v nachale XX stoletiia: Rozhdenie i gibel' ideologii Vse-rosiiskogo natsional'nogo soiuza (Moscow: ROSSPEN, 2001).

75 Beyrau, Militär und Gesellschaft, 423-429.

76 M. I. Gusev, "Opyt razrabotki voprosa o sravnitel'noi godnosti k otbyvaniiu voisnkoi povinnosti razlichnykh natsional'nostei, komlektuiuschikh russkuiu armiu," Voenno-Meditsinskii zhurnal 6 (1910): 309-344. 
works. Yet the starting point of his research undermined all the efforts of his predecessors: In Gusev's view, Miliutin's reforms and the introduction of allsoslovie conscription in 1874 had been mistakes from both the political and biological perspectives.

General conscription, as it is known, aimed at equal distribution of the burdens of service among a population of different ethnographic groups; this is, indeed, a fair approach. Yet its practical realization was possible only under the condition of equal physical abilities of all recruits. The material that we studied shows that this is not the case and that different national groups differ radically in their fitness for military service $\left[\ldots .{ }^{77}\right.$

Gusev's materials were the medical files of the Odessa military hospital dealing with soldiers "rejected" [oprotestovannye] by the garrison physicians. Since the files dated from 1907-1908, and thus did not include "nationality," Gusev replicated familiar manipulations based on religion, ethnicity, and place of birth. Like his predecessors, he faced the necessity of constructing Russians from the various Orthodox Christians, but, unlike them, he was irritated by the fact that Orthodox Georgians and Moldavians could join the constructed Russian national collective. Accepting the inevitability of such "mistakes," Gusev justified them (and his method) by stressing that their inclusion would lower Russian scores and subject Russian "fitness" to an especially stringent test. $^{78}$ The inferiority of non-Russians, even those of the Orthodox faith, was for Gusev axiomatic.

Gusev added a new category to the earlier organization of data by frequency of disease or racial traits. He collected all inorodtsy in one group, directly opposing them to Russians and concluding that inorodtsy were rejected twice as often as Russians. ${ }^{79}$ Such an approach split the imperial army into two distinct organisms. "Great," "Little," and "White," as components of the racially superior "Russian" organism, lost the national status and territories granted them by Gusev's predecessors. In his conclusions, Gusev saw incontestable proof of his own opening statement: The burden of military service was distributed unevenly because some non-Russian nations were organically "unfit" to serve in the army. The new army would have to be composed of "the crèmede-la-crème physical element" represented by "Russians."

The latter assertion aimed at the heart of the imperial army as an instrument of integration. The military-anthropological tradition had routinely connected the study of the military body with a larger discussion of the social and national collectives that supplied recruits. The ideas advanced by Gusev

77 lbid., 343.

78 lbid., 318.

79 Ibid., 327-328. 
suggested a different model of society itself: a Russian core surrounded by a racially inferior, unreliable, non-Russian periphery whose political and social rights were justifiably limited.

\section{Russian Military Anthropology's Last Stand}

The Great War interrupted the systematic anthropological study of the imperial army's "contingents." The war required total mobilization of the combatants' economic, political, and human resources. In Russia, this lent support to the ideal of a strong and motivated national army that would represent the best elements of the Russian imperial state and society and be capable of fighting alongside modern European nations for a new world order based on national principles and rational governance. Those who did not represent the interests of "the best elements," or were deemed unlikely to share collective Russian interests, would be put aside to make way for the emerging nation. The war decisively transformed Jews, formally a potentially "unreliable" contingent, into an internal enemy that had to be resettled from the front line to the interior. Germans, Lithuanians, Latvians, Poles, and Armenians shared in their fate. ${ }^{80}$

Yet, the mass mobilization of civilians in the course of the war made ethnic cleansing and Russification of the army de facto impossible. Against a background of social polarization and ideological radicalization, crises of authority, and the growing disintegration and demoralization of the army, military anthropology's professional reformism came to be seen as a limited and inadequate solution and lost its credibility. As the conflict progressed, the language of nationality gained in importance. Governments of the countries at war, as well as those who intended to sponsor the postwar system (the Wilson administration), along with political opponents of the regime inside Russia, championed the principle of "national rights." For the Russian Empire, this principle was a death knell. ${ }^{81}$ As Steven A. Smith writes, World War I revealed the inability of both old and new imperial political elites and military professionals in

80 On population deportations in the Russian Empire during World War I, see Gatrell, A Whole Empire Walking; Lohr, Nationalizing the Russian Empire; S. G. Nelipovich, "Repressii protiv podannykh 'tsentral'nykh derzhav': Deportatsii v Rossii," Vorenno-istoricheskii zhurnal 6 (1996): 42-52. See an especially interesting analysis of racial treatment of baptized Jews in the war years by Eugene Avrutin, "Kreschenye evrei, etnicheskii konflikt, i politika povsednevnoi zhizni v Rossii vo vremia mirovoi voiny," in Mirovoi Krizis 1914-1920 godovi sud'by vostochnoevropeiskogo evre-istva, ed. Oleg Budnitskii (Moscow: ROSSPEN, 2005), 99-123.

81 See Aviel Roshwald, Ethnic Nationalism and the Fall of Empires: Central Europe, Russia and the Middle East, 1914-1923 (New York: Routledge, 2001). 
Russia to carry out either of the major models for modernization that were advanced during the prewar decades: Russification of the Empire and the army, or the incorporation of non-Russian elements under the slogan of egalitarian patriotism. ${ }^{82}$ The Russian army could not stand up to the demands of modern warfare, but its physical "unfitness" was no longer an issue. The issue was now political "fitness," in both the army and society in general.

In late 1916, the well-known academician Sergey F. Ol'denburg, chairman of the Imperial Russian Geographical Society's Ethnographic Division, learned of the German ethnographic project to study the ethnic makeup of outlying Russian imperial territory recently occupied by Germany. The study aimed to justify the establishment of nationally based administrative units (Lithuanian, Belorussian). ${ }^{83}$ Ol'denburg was outraged by the Russian government's ignorance of these territories and its reliance on descriptive reports of provincial governors-general and "scientific" data provided by military statisticians whom he characterized as inept. A new committee composed of civilian scholars not compromised by service to the old regime-anthropologists, ethnographers, linguists, and geographers-was needed to support Russian war efforts and provide a basis for postwar political and territorial arrangements. The subsequent establishment of the Commission for the Study of the Tribal Composition of the Population of the Borderlands of Russia (KIPS) was, in part, an answer to the failure of the military's applied science to produce the modern army and the modern "empire of knowledge." ${ }^{84}$ Emerging in early February 1917, under the auspices of the Academy of Sciences, KIPS received genuine official recognition only under the Bolshevik government. ${ }^{85}$

The state-sponsored Russian military anthropology that had empowered researchers by providing live subjects for large-scale studies displayed certain parallels and continuity with the anthropological projects of the Soviet epoch of mass civilian mobilization. But the comparison is superficial; Soviet initiatives no longer aimed at integration or Russification. In Soviet Russia,

82 Steven A. Smith, "Citizenship and the Russian Nation during World War I: A Comment," Slavic Review 59, no. 2 (2000): 316-329, esp. 322.

83 On German activities on the Russian western borderlands, see Wiktor Sukiennicki, East Central Europe during World War I: From Foreign Domination to National Independence, 2 vols., ed. Maciej Siekierski (Boulder, CO: East European Monographs; New York: Columbia University Press, 1984): Vol. 1, 159-166.

84 I borrowed this metaphor from Alexander Vucinich, Empire of Knowledge: The Academy of Sciences of the USSR (1917-1970) (Berkeley, CA: University of California Press, 1984).

85 The best analysis of KIPS activities can be found in Francine Hirsch, Empire of Nations: Ethnographic Knowledge and the Making of the Soviet Union (Ithaca, NY: Cornell University Press, 2005). 
traditional ethnography pushed physical anthropology to the margins, ${ }^{86}$ which then found a home in the eugenics movement of the 1920s. ${ }^{87}$ In the words of Mark Adams,

Eugenics fit ideally the new emphasis on science as a way of undermining religion and improving the human condition; it entailed a scientistic, materialist, biosocial concept of human condition; it sought to apply the results of genetics to benefit society; and it emphasized the human power to shape the future. ${ }^{88}$

The eugenicist agenda's presence among the pre-1917 military anthropologists had been very limited; their orientation had been thoroughly pragmatic, and their social engineering ambitions were limited by the ideology of the War Ministry. The anthropological projects born of the Great War were studies of a displaced and starving population, but such studies became possible on a large scale only after the civil war, during the early Soviet state-building of the 1920s. Generally, they were carried out by civilian anthropologists, traditionally interested in imperial diversity, who had never before enjoyed state support. With the reconfiguration of the former imperial space and the disruption of funding for expeditions to distant corners of the former empire, they found their sole sponsor in the Soviet state and its consolidated medical commands or social assistance groups, investigating the impact of war on human "resources." The new military and eugenic concerns allowed them to survive professionally under the new regime.

Thus, however tempting it may be to reject 1917 as a major dividing line in Russian historical narrative, the old chronological orthodoxy should remain unchanged in the case of military anthropology. Its story as part of the ideological context of the ancien régime ended with the Great War and the Revolution. As an embodiment of the ideal of the "nation in arms," the Red Army faced the same challenges of ethnic and regional diversity as the old Imperial Army. However, for ideological reasons, there was no place for military anthropologists and their recommendations on optimum strategies for the integration of minorities; with ethnic and confessional variations reformulated in terms of social and class differences, their place had been usurped by the commissars.

86 For a superb analysis of the ethnographers' role in defining the language of Soviet nationality politics, see Hirsch, Empire of Nations.

87 On eugenics in Russia, see Mark B. Adams, "Eugenics in Russia, 1900-1940" in The Wellborn Science: Eugenics in Germany, France, Brazil, and Russia, ed. idem (Oxford: Oxford University Press, 1990), 153-216. 